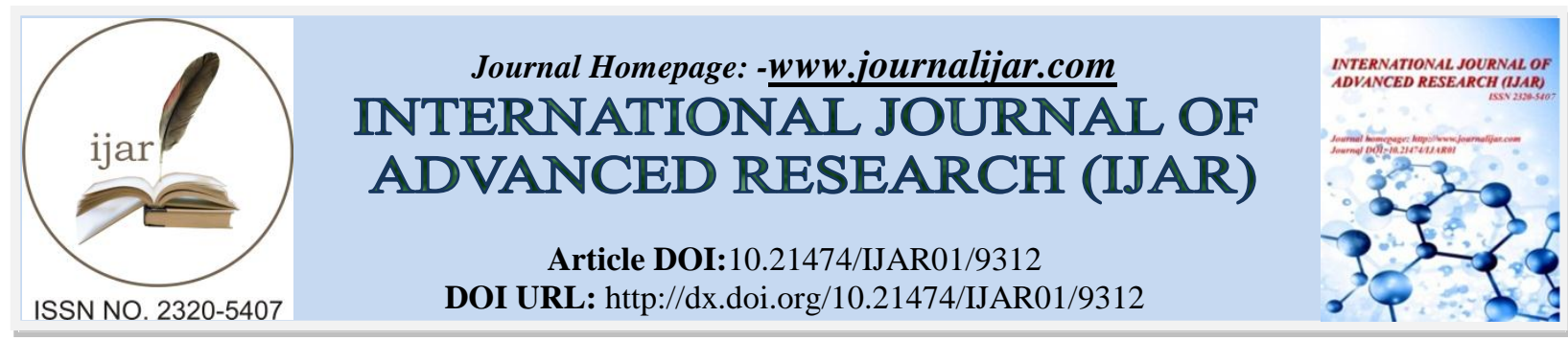

RESEARCH ARTICLE

\title{
FORMULATION AND EVALUATION OF FAST DISSOLVING ORAL FILMS CONTAINING LOSARTAN POTASSIUM.
}

Deepak Kumar Sarangi ${ }^{1}$, Suman Kumar Mekap ${ }^{2}$ and Monalisa Mahapatra ${ }^{2}$.

1. Department of Pharmaceutics, Roland Institute of Pharmaceutical Sciences, Brahmapur, Odisha, INDIA.

2. School of Pharmacy, Centurion University Bhubaneswar, Odisha, India.

\section{Manuscript Info}

Manuscript History

Received: 15 April 2019

Final Accepted: 17 May 2019

Published: June 2019

Key words:-

Oral film,Losartan Potassium, PVA,

PVP, HPMC, Carbopol, Pectin and Tragacanth.

\section{Abstract}

The fast dissolving oral film were prepared using different polymers like PVA, PVP, HPMC, Carbopol, Pectin and Tragacanth by solvent casting method. The fast Dissolving oral film evaluated for folding endurance, swelling index, surface $\mathrm{pH}$, in vitro disintegration time, drug content, drug polymer compatibility by FTIR Study, Scanning electron microscopy and in vitro drug release. The physical appearance and folding endurance properties were found to be good and electron microscopy shows that films are clear, colourless with smooth surface without any scratches. The average folding endurance time within the range of 112 to 208. The drug content showed uniform mixing of drug in all prepared fast dissolving films. The invitro drug release showed 78 to $96 \%$ drug release within 5 minutes. Drug release obeys the first order kinetics. The prepared films were stable. Hence it can be inferred that the fast dissolving oral film of losartan potassium may produce the rapid action thereby improving bioavailability and enhance the absorption by avoiding the first pass effect. Keywords: Losartan Potassium, PVA, HPMC, fast dissolving film.

\section{Introduction:-}

Recent developments in technology have presented viable dosage alternatives for patients who may have difficulty in swallowing of tablets or liquids. Conventionally oral solid dosage form are administered with a glass of water may be inconvenient or impractical for some patients ${ }^{1}$. The oral cavity has been investigated as a site for drug delivery from a long period of time about $60 \%$ of the total dosage form are administered by oral route $^{2}$. Among the different routes of administration, the oral route of administration continues to be most preferred route due to various advantages including ease of administration, avoidance of pain, versatility and most importantly patient compliance. One such relatively new dosage form is the oral strip, a thin film that is prepared using hydrophilic polymers that rapidly dissolves on the tongue or buccal cavity. Recently, fast dissolving drug delivery system have started gaining popularity and acceptance as new drug delivery systems, because they are easy to administer and lead to better compliance. These delivery systems either dissolve or disintegrate in mouth rapidly, without requiring any water to aid in swallowing ${ }^{3}$ . They also impart unique product differentiation, thus enabling use as line extensions for existing commercial products. This novel drug delivery system can also be beneficial for meeting the current needs of the 
industry for improved solubility/ stability, biological half life and bioavailability enhancement of drugs ${ }^{4}$. Nearly 35-50 percent of the general population, especially the elderly and children suffer from dysphagia or difficulty in swallowing, which results in high incidence of non-compliance and ineffective therapy. Other group who may experience problems in swallowing conventional oral dosage form are the patients with reduced liquid intake or patients suffering from nausea, as well as patients travelling or who do not have easy access to water. The swallowing problems are also common in some cases such as patients with motion sickness, sudden episodes of allergic attack or coughing and due to no access of water. Many pharmaceutical dosage forms are administered in the form of pills, Granules, powders and liquids. Generally, a pill is designed for swallowing intact or Chewing to deliver a precise dosage of medication to patients. The pills, which include tablet and capsules, are able to retain their shapes under moderate pressure. However, some Patient, particularly pediatric and geriatric patients, have difficulty in swallowing or chewing solid dosage forms ${ }^{5},{ }^{6}$. Many pediatric and geriatric patients are unwilling to take these solid preparations due to fear of choking ${ }^{7}$. Although oral disintegrating tablets have an advantage of administration without choking and fast disintegration; the disintegrated materials contained in them are insoluble and remain same until swallowing. In such cases formulation of fast dissolving film will be advantageous ${ }^{8,9}$. Hence orally dissolving tablets have come into existence. Even with these Differences, most of the existing oral dissolving drug delivery systems are in the form of solid tablets and designed to dissolve/disintegrate in the patient's mouth without the need to drink or chew. However, the fear of taking solid tablets and the risk of choking for certain patient populations still exist despite their short disintegration or dissolution times. Hence mouth dissolving oral film drug delivery is a better alternative in such cases.Many drugs given orally are poor in bioavailability because of the $\mathrm{pH}$ of the stomach, the presence of enzymes, and extensive first-pass metabolism. Traditionally, these drugs have been administered by parenteral route, which invariably lead to poor patient compliance .This made the pharmaceutical industries to look for alternative routes of drug delivery system. Intra oral fast-dissolving drug delivery system where in the dosage form (film) will be placed on the surface of the tongue or in the oral/buccal cavity, where drug release rapidly for local and systemic absorption.

\section{Material:-}

Losartan potassium is obtained as gift sample from Micro labs, Bangalore., Carbopol934p purchased from Rajesh chemicals, Mumbai., Poly vinyl alcohol, Poly vinyl pyrrolidone k-30, HPMC E-15, Pectin ,Traganth gum, Aspartame, Croscarmellose sodium, Propylene glycol Sodium starch glycolate are obtained from SD Fine Chem. Ltd. Mumbai.

\section{Method:-}

Oral fast dissolving film was prepared by solvent casting method. Aqueous solution I was prepared by dissolving film forming polymer, in specific proportion in distilled water and allowed to stirred for 3 hours and kept for 1 hour to remove all the air bubble entrapped or remove bubbles. Aqueous solution II was prepared by dissolving the pure drug, sweetener, and plasticizer in specific proportion in distilled water. The aqueous solution I and II were mixed and stirred for 1 hour. The solution were cast on to $9 \mathrm{~cm}$ diameter Petri dish and were dried in the oven at $45^{\circ} \mathrm{C}$ for 12 hours. The film was carefully removed from surface of petridish and cut according to size required for testing(square film $1.5 \mathrm{~cm}$ length, $1.5 \mathrm{~cm}$ width). The samples were stored in glass container maintained at a temperature $30^{\circ} \mathrm{C}$ and relative humidity $60 \% \pm 5 \%$ until further analysis.

\section{Formulation of fast dissolving film of losartan potassium: Calculation of dose for losartan potassium:}

The dose of losartan potassium is $25 \mathrm{mg}$. Therefore amount of Losartan potassium required in $3 \mathrm{~cm}(1.5 \mathrm{x} 1.5)$ is 25 mg.

1. Area of film of $1.5 \mathrm{X} 1.5 \mathrm{sq} . \mathrm{cm}$ is $2.25 \mathrm{sq} . \mathrm{cm}$.

2. Area of petridish of $6 \mathrm{~cm}$ diameter is $28.26 \mathrm{sq} . \mathrm{cm}$.

3. Amount of drug present in $2.25 \mathrm{sq} . \mathrm{cm}$ of film is $25 \mathrm{mg}$.

4. Amount of drug present in $28.26 \mathrm{sq} . \mathrm{cm}$ of petridish is $314 \mathrm{mg}$.

Therefore, $2.25 \mathrm{sq} . \mathrm{cm}$ of film should contain $25 \mathrm{mg}$ of drug. It is fixed for all formulations. 
Table 1:-Composition of various formulations

\begin{tabular}{|c|c|c|c|c|c|c|c|c|c|c|c|c|c|c|c|}
\hline $\begin{array}{l}\text { Formulation } \\
\text { code }\end{array}$ & F1 & F2 & F3 & F4 & F5 & F6 & F7 & F8 & F9 & $\begin{array}{c}\text { F1 } \\
\text { 0 }\end{array}$ & $\begin{array}{c}\text { F1 } \\
1\end{array}$ & $\begin{array}{c}\text { F1 } \\
2\end{array}$ & $\begin{array}{c}\text { F1 } \\
3\end{array}$ & $\begin{array}{c}\text { F1 } \\
4\end{array}$ & $\begin{array}{c}\text { F1 } \\
5\end{array}$ \\
\hline $\begin{array}{c}\text { Losartan } \\
\text { potassium(gm) }\end{array}$ & $\begin{array}{c}3.1 \\
4 \\
\end{array}$ & $\begin{array}{c}3.1 \\
4\end{array}$ & $\begin{array}{c}3.1 \\
4\end{array}$ & $\begin{array}{c}3.1 \\
4 \\
\end{array}$ & $\begin{array}{c}3.1 \\
4 \\
\end{array}$ & $\begin{array}{c}3.1 \\
4\end{array}$ & $\begin{array}{c}3.1 \\
4 \\
\end{array}$ & $\begin{array}{c}3.1 \\
4 \\
\end{array}$ & $\begin{array}{c}3.1 \\
4 \\
\end{array}$ & $\begin{array}{c}3.1 \\
4\end{array}$ & $\begin{array}{c}3.1 \\
4\end{array}$ & $\begin{array}{c}3.1 \\
4\end{array}$ & $\begin{array}{c}3.1 \\
4\end{array}$ & $\begin{array}{c}3.1 \\
4\end{array}$ & $\begin{array}{c}3.1 \\
4 \\
\end{array}$ \\
\hline PVA \%W/V & 2.0 & 1 & - & - & 1.0 & - & 2 & - & - & - & 1.5 & - & 2.0 & 1.5 & - \\
\hline PVP \%W/V & 0.5 & - & 0.5 & 0.5 & - & - & - & - & - & - & - & - & - & - & $\begin{array}{c}0.2 \\
0\end{array}$ \\
\hline HPMC \%W/V & - & 1.5 & 2.0 & - & - & 1.5 & - & 2 & - & - & 1.0 & 2.0 & - & 1.0 & 2.0 \\
\hline $\begin{array}{c}\text { Carbopol } \\
\% \text { w/v }\end{array}$ & - & - & - & - & - & - & $\begin{array}{c}0.2 \\
0\end{array}$ & $\begin{array}{c}0.2 \\
0\end{array}$ & $\begin{array}{c}0.2 \\
0\end{array}$ & - & - & - & - & - & - \\
\hline Pectin \%w/v & - & - & - & 2.0 & 1.5 & 1 & - & - & 2.0 & 2.0 & - & - & - & - & - \\
\hline $\begin{array}{c}\text { Tragacanth } \\
\% \text { w/v }\end{array}$ & - & - & - & - & - & - & - & - & - & $\begin{array}{c}0.2 \\
0\end{array}$ & - & $\begin{array}{c}0.2 \\
0\end{array}$ & $\begin{array}{c}0.2 \\
0\end{array}$ & - & - \\
\hline $\begin{array}{c}\text { Sodium starch } \\
\text { glycolate } \\
\% \mathrm{~W} / \mathrm{w}\end{array}$ & - & - & - & - & - & - & - & - & - & - & - & - & - & $\begin{array}{c}25 . \\
0\end{array}$ & - \\
\hline $\begin{array}{c}\text { Croscarmellos } \\
\text { e sodium } \\
\% \mathrm{~W} / \mathrm{w} \\
\end{array}$ & - & - & - & - & - & - & - & - & - & - & - & - & - & - & $\begin{array}{c}30 . \\
0\end{array}$ \\
\hline $\begin{array}{c}\text { Aspartame \% w } \\
\text { /v Polymer }\end{array}$ & 7.0 & 7.0 & 7.0 & 7.0 & 7.0 & 7.0 & 7.0 & 7.0 & 7.0 & 7.0 & 7.0 & 7.0 & 7.0 & 7.0 & 7.0 \\
\hline $\begin{array}{c}\text { Proplyene } \\
\text { Glycol } \% \text { w/w } \\
\text { of polymer }\end{array}$ & $\begin{array}{c}30 . \\
0\end{array}$ & $\begin{array}{c}30 . \\
0\end{array}$ & $\begin{array}{c}30 . \\
0\end{array}$ & $\begin{array}{c}30 . \\
0\end{array}$ & $\begin{array}{c}30 . \\
0\end{array}$ & $\begin{array}{c}30 . \\
0\end{array}$ & $\begin{array}{c}30 . \\
0\end{array}$ & $\begin{array}{c}30 . \\
0\end{array}$ & $\begin{array}{c}30 . \\
0\end{array}$ & $\begin{array}{c}30 . \\
0\end{array}$ & $\begin{array}{c}30 . \\
0\end{array}$ & $\begin{array}{c}30 . \\
0\end{array}$ & $\begin{array}{c}30 . \\
0\end{array}$ & $\begin{array}{c}30 . \\
0\end{array}$ & $\begin{array}{c}30 . \\
0\end{array}$ \\
\hline
\end{tabular}

\section{Result \& Discussion:-}

Standard plot of Losartan potassium in PH 6.8 phosphate buffer:

$100 \mathrm{mg}$ of losartan potassium was accurately weighed and dissolve into $100 \mathrm{ml}$ volumetric flask containing $\mathrm{pH} 6.8$ buffer solution to get a concentration of $(1000 \mu \mathrm{g} / \mathrm{ml})$ i.e. stock solution-I. from this $1 \mathrm{ml}$ was withdrawn and diluted to $100 \mathrm{ml}$ with $\mathrm{pH} 6.8$ phosphate buffer, to get a concentration of $(10 \mu \mathrm{g} / \mathrm{ml})$ i.e. Stock solution-II.

\section{Calibration curve in ph 6.8 phosphate buffer solution:}

From the stock solution-II, 1,2,3,4,5,6,7,8and 9ml sample were withdrawn and volume was made up to the mark with $\mathrm{pH} 6.8$ phosphate buffer. This solution gives $1,2,3,4,5,6,7,8$, and $9 \mu \mathrm{g} / \mathrm{ml}$ concentration of losartan potassium. The absorbance of these solutions measured in UV at $203 \mathrm{~nm}$ using $\mathrm{pH} 6.8$ phosphate buffer as blank.

Table 2:-calibration Losartan potassium in $6.8 \mathrm{pH}$ phosphate buffer:

\begin{tabular}{|r|c|l|}
\hline Sl. NO & CONCENTRATION $(\mathrm{mcg} / \mathrm{ml})$ & ABSORBANCE \\
\hline 1 & 0.00 & 0.00 \\
\hline 2 & 01 & 0.182 \\
\hline 3 & 03 & 0.300 \\
\hline 4 & 05 & 0.493 \\
\hline 5 & 07 & 0.695 \\
\hline 6 & 09 & 0.903 \\
\hline
\end{tabular}

Drug- excipient compatibility studies lay the foundation for designing a chemically stable formulation for clinical and commercial development. Drug excipient compatibility studies are conducted during preformulation to select the most appropriate excipients. 
It is clear from the below observation of the below values of characteristics absorption bands for different functional groups and bonds of the drug and its polymer that is most of the cases there is no appreciable change in the position of the bands. Even if negligible deviation exist, its due to the different types of the polymers used for the study.

Table 3:-FTIR (KBr) cm-1:

\begin{tabular}{|c|c|c|c|c|c|c|c|c|}
\hline $\begin{array}{l}\text { Positsons } \\
\text { of the } \\
\text { bond cm- } \\
1\end{array}$ & $\begin{array}{l}\text { Pure } \\
\text { drug }\end{array}$ & PVA & PVP & $\mathbf{C P}$ & PECTIN & HPMC & TRAGACANTH & Remark \\
\hline $\begin{array}{l}3200- \\
3350\end{array}$ & $\begin{array}{l}3200- \\
3350\end{array}$ & - & - & $\begin{array}{l}3200- \\
3350\end{array}$ & $\begin{array}{l}3200- \\
3350\end{array}$ & - & - & $\begin{array}{c}\text { Brord peak hydrogen } \\
\text { bonded } \\
-\mathrm{OH} \text { of } \mathrm{CH} 2 \mathrm{OH}\end{array}$ \\
\hline $\begin{array}{l}2929- \\
2863\end{array}$ & $\begin{array}{l}2929- \\
2863\end{array}$ & $\begin{array}{l}2929- \\
2864\end{array}$ & $\begin{array}{l}2929- \\
2864\end{array}$ & $\begin{array}{l}2929- \\
2865\end{array}$ & $\begin{array}{l}2932- \\
2866\end{array}$ & $\begin{array}{l}2926- \\
2867\end{array}$ & $\begin{array}{l}2928- \\
2861\end{array}$ & $\begin{array}{c}\mathrm{C}-\mathrm{H} \text { stretching bond, } \mathrm{CH} 2 \\
\text { and } \mathrm{CH} 3 \text { groups. }\end{array}$ \\
\hline 1643 & 1643 & 1643 & 1643 & - & 1639 & 1640 & 1640 & $\mathrm{C}=\mathrm{N}$ gropup. \\
\hline $\begin{array}{l}1572- \\
1507\end{array}$ & $\begin{array}{l}1572- \\
1507\end{array}$ & $\begin{array}{l}1576- \\
1500\end{array}$ & 1515 & 1549 & 1509 & 1507 & 1502 & $\begin{array}{c}\mathrm{C}=\mathrm{C} \text { ring } \\
\text { stretching }(\text { aromatic ring })\end{array}$ \\
\hline $\begin{array}{c}1460- \\
1352\end{array}$ & $\begin{array}{l}1460- \\
1461\end{array}$ & $\begin{array}{l}1461- \\
1352\end{array}$ & $\begin{array}{c}1462- \\
1370\end{array}$ & $\begin{array}{l}1454- \\
1352\end{array}$ & $\begin{array}{l}1457- \\
1356\end{array}$ & $\begin{array}{c}1459- \\
1359\end{array}$ & $\begin{array}{l}1461- \\
1355\end{array}$ & $\begin{array}{c}\mathrm{C}-\mathrm{H} \text { bending of } \mathrm{CH} 3 \text { and } \\
\mathrm{CH} 2 \text { groups }\end{array}$ \\
\hline 1425 & 1425 & 1426 & 1430 & 1411 & 1424 & 1424 & 1424 & $\mathrm{C}-\mathrm{N}$ \\
\hline 1257 & 1257 & 1258 & 1264 & 1254 & 1254 & 1257 & 1258 & $\mathrm{O}-\mathrm{H}$ bending \\
\hline $837-760$ & $\begin{array}{l}837- \\
760\end{array}$ & $\begin{array}{c}837- \\
760\end{array}$ & $\begin{array}{c}839- \\
760\end{array}$ & $\begin{array}{l}839- \\
760\end{array}$ & $838-757$ & $\begin{array}{l}839- \\
753\end{array}$ & $839-761$ & $\begin{array}{l}\text { 1,4 disubstituted phenyl } \\
\text { ring } 1,3 \text { disubstituted } \\
\text { phenyl ring }\end{array}$ \\
\hline
\end{tabular}
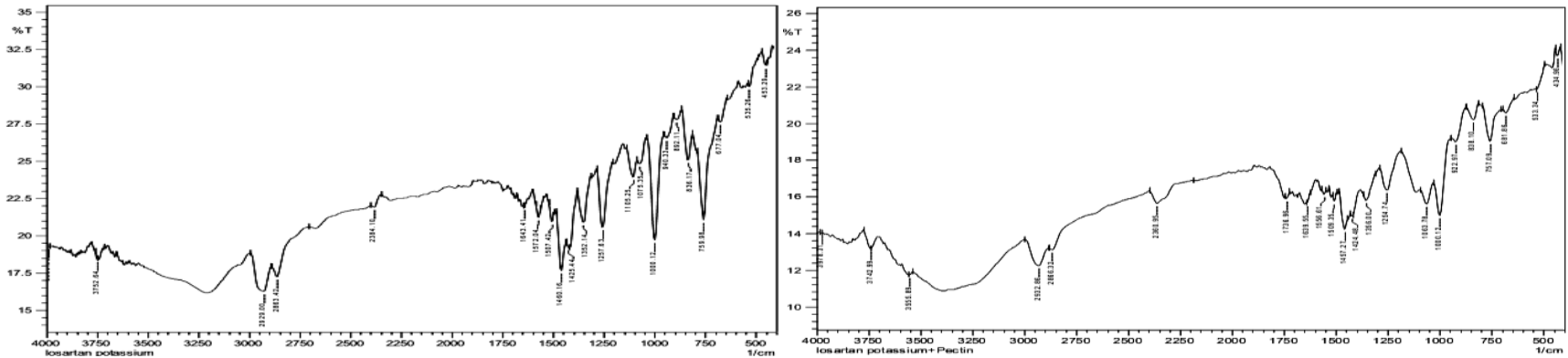

Fig 2:-Ftir Of Pure Drug(Losartan Potassium)

Fig 6:-Ftir Of Drug + Pectin

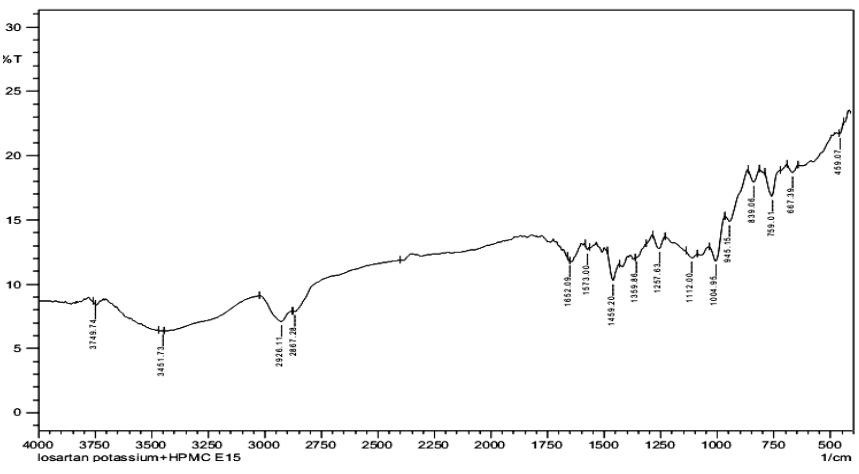

Fig 3:-FTIR OF DRUG + CARBOPOL 934p

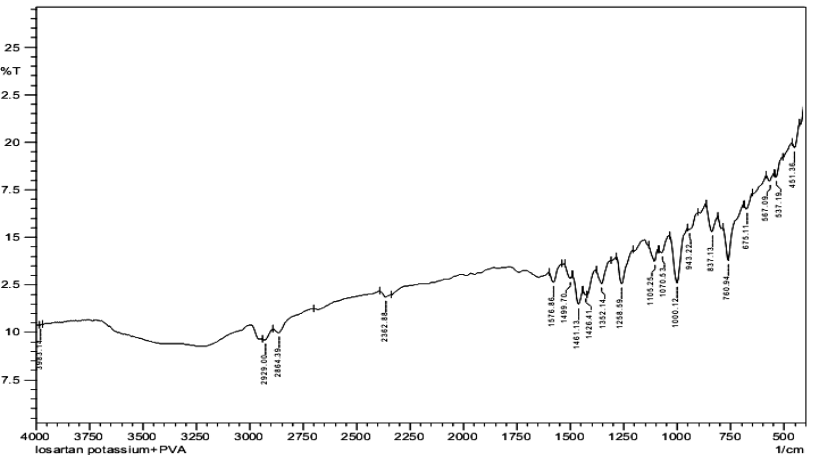

Fig 7:-FTIR OF DRUG + PVA 


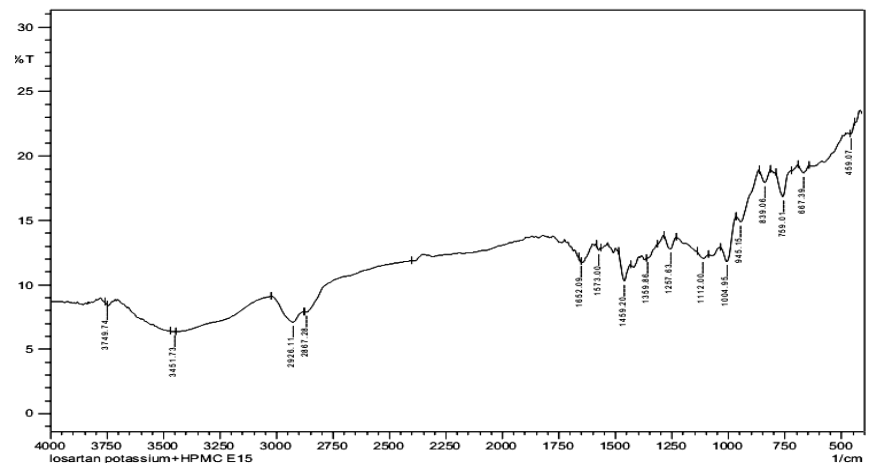

Fig 4:-FTIR OF DRUG + HPMC E-15

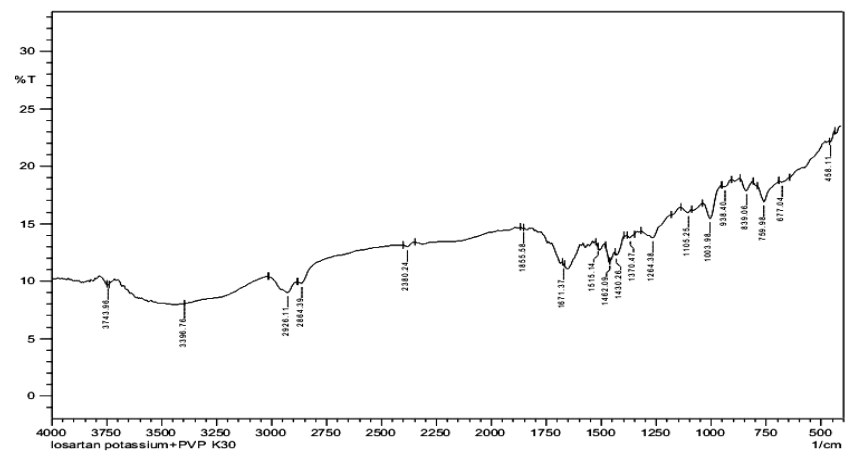

Fig 5:-FTIR OF DRUG + PVP K-30

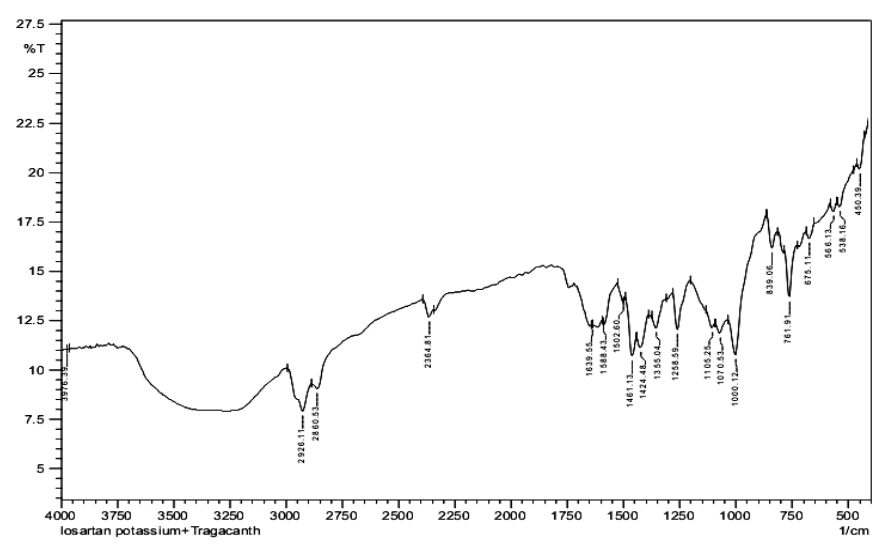

Fig 8:-Ftir Of Drug + Tragacanth

Scanning electron microscopy:
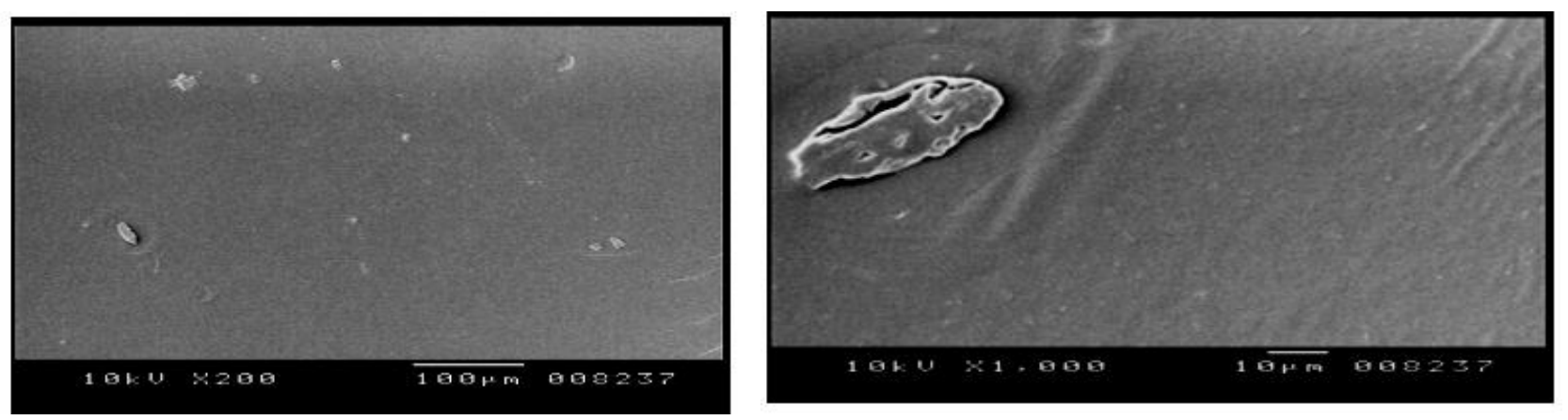

Fig 9:-Scanning electron microscopy photograph of fast dissolving film of losartanpotassium with PVA. 

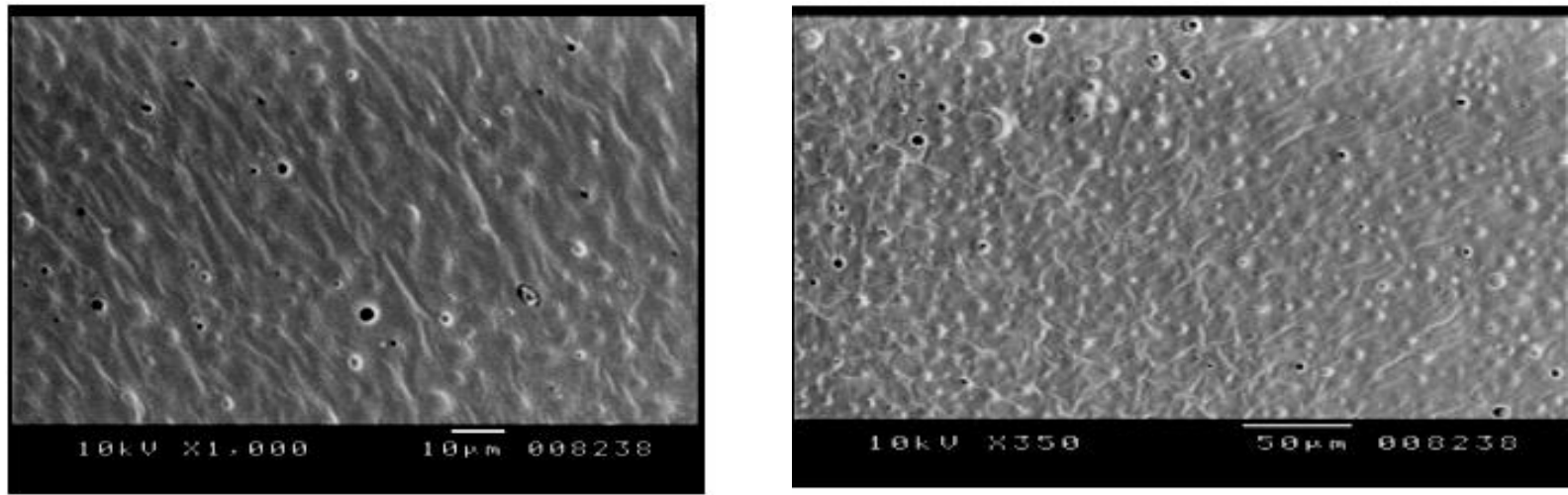

Fig 10:-Scanning electron microscopy photograph of fast dissolving film of losartan potassium with HPM

\section{Evaluation}

\section{Weight uniformity of films:}

All the films are within the weight range of $43.10 \pm 0.110$ to $60.29 \pm 1.210 \mathrm{mg}$ indicates that all the films are in uniform weight with minimum standard deviation.

\section{Moisture uptake:}

All the films are free from the moisture uptake and there is no evidence of Moisture attack in the prepared films and data shown in table 4.

\section{Thickness of films:}

The thickness of the film was measured using vernier calipers. The thickness was almost uniform in all the formulations and values ranges from $0.7 \pm 0.057 \mathrm{~mm}$ to $1.1 \pm 0.100 \mathrm{~mm}$. The standard deviation values indicated that all the formulations were within the range. The results of thickness for films were shown in Table 4 .

\section{Folding endurance:}

The folding endurance of the films was determined by repeatedly folding a Small strip of films at the same place till it breaks and the folding endurance data of all the films is given in table 4.

Among all the formulations, Formulation F1 to F3 showed minimum folding Endurance time which is indicate that these fast dissolving films are excellent in Flexibility as compared to other formulations.

Table 4:-Evaluation of fast dissolving oral film of losartan potassium

\begin{tabular}{|l|l|c|l|l|}
\hline Formulation & Weight(mg) & Moisture uptake & Thickness(mm) & Folding \\
\hline F1 & $48.00 \pm 1.00$ & Nil & $0.7 \pm 0.115$ & $112 \pm 2.517$ \\
\hline F2 & $47.66 \pm 1.528$ & Nil & $0.8 \pm 0.057$ & $123 \pm 3.215$ \\
\hline F3 & $47.21 \pm 1.00$ & Nil & $0.7 \pm 0.057$ & $123 \pm 4.726$ \\
\hline F4 & $50.32 \pm 1.432$ & Nil & $1.1 \pm 0.010$ & $144 \pm 3.215$ \\
\hline F5 & $43.10 \pm 0.522$ & Nil & $0.9 \pm 0.152$ & $133 \pm 4.509$ \\
\hline F6 & $47.10 \pm 0.574$ & Nil & $0.9 \pm 0.200$ & $149 \pm 2.082$ \\
\hline F7 & $56.25 \pm 0.362$ & Nil & $1.1 \pm 0.173$ & $171 \pm 3.606$ \\
\hline F8 & $57.45 \pm 0.220$ & Nil & $1.1 \pm 0.100$ & $184 \pm 4.041$ \\
\hline F9 & $60.29 \pm 1.210$ & Nil & $1.1 \pm 0.100$ & $197 \pm 2.517$ \\
\hline F10 & $49.27 \pm 0.572$ & Nil & $0.8 \pm 0.057$ & $162 \pm 3.606$ \\
\hline F11 & $52.14 \pm 0.528$ & Nil & $0.9 \pm 0.057$ & $133 \pm 3.055$ \\
\hline F12 & $56.20 \pm 0.577$ & Nil & $0.8 \pm 0.100$ & $208 \pm 2.887$ \\
\hline F13 & $50.12 \pm 0.320$ & Nil & $1.1 \pm 0.057$ & $201 \pm 3.512$ \\
\hline F14 & $51.12 \pm 0.336$ & Nil & $1.1 \pm 0.100$ & $142 \pm 3.055$ \\
\hline F15 & $52.29 \pm 0.385$ & Nil & $1.1 \pm 0.100$ & $141 \pm 3.606$ \\
\hline
\end{tabular}




\section{Drug content uniformity:}

The drug content uniformity was performed for all the 15 formulations and Results are shown in Table 5. The percentage drugs content of the fast dissolving Films were found to be between $88.33 \%$ \pm 0.027 to $98.68 \% \pm 0.034$ of losartan potassium. The results were within the range and that indicated uniformity of mixing and given in table.

In vitro disintegration time of films:

The in vitro disintegration time is calculated by the time taken by film to Under go complete disintegration.Electrolab Disintegration test apparatus (USP) maybe used for this study. The disintegration time of different formulation was shown in table 5. The in vitro disintegration time of all the formulations within the range of $16 \pm 1.528$ to $49 \pm 2.887$ seconds fulfilling the official requirements. As the concentration of the super disintegrant increases the in vitro disintegration time of the film also decreases.

\section{Swelling index:}

The studies for swelling index is carried out in $\mathrm{pH} 6.8$ phosphate buffer solution.

The formulation F14 and F15 showed higher swelling index as compared to the other formulations due to the more water absorption of the super disintegrants.

\begin{tabular}{|c|c|c|c|c|}
\hline \multirow{2}{*}{ Time (sec) } & \multicolumn{5}{|c|}{ \%cumulative amount of drug release } \\
& \multicolumn{4}{|c|}{} \\
\cline { 2 - 5 } & F1 & F2 & F3 & F4 \\
\hline $\mathbf{0}$ & 0 & 0 & 0 & 0 \\
\hline $\mathbf{3 0}$ & $26.95 \pm 0.003$ & $20.49 \pm 0.003$ & $19.12 \pm 0.015$ & $22.44 \pm 0.015$ \\
\hline $\mathbf{6 0}$ & $37.87 \pm 0.035$ & $34.31 \pm 0.005$ & $30.39 \pm 0.011$ & $40.20 \pm 0.012$ \\
\hline $\mathbf{9 0}$ & $59.24 \pm 0.010$ & $57.03 \pm 0.006$ & $51.32 \pm 0.015$ & $56.09 \pm 0.009$ \\
\hline $\mathbf{1 2 0}$ & $72.10 \pm 0.005$ & $73.60 \pm 0.008$ & $70.01 \pm 0.014$ & $71.09 \pm 0.005$ \\
\hline $\mathbf{1 5 0}$ & $88.56 \pm 0.009$ & $85.17 \pm 0.006$ & $86.07 \pm 0.015$ & $89.11 \pm 0.003$ \\
\hline
\end{tabular}

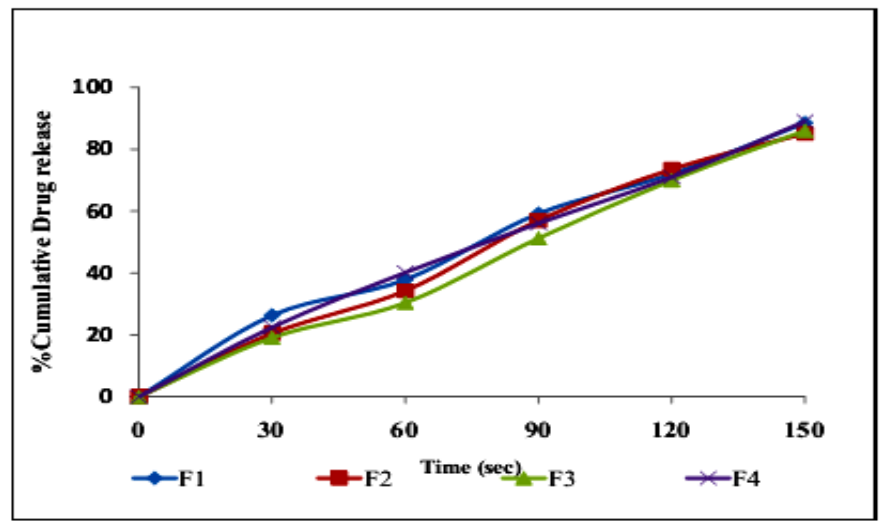

Table 6:-Cumulative \% Drug Release (F1 - F4)

Fig 11:-Dissolution Profile of F1-F4

\begin{tabular}{|c|c|c|c|}
\hline \multirow{2}{*}{ Time (Min) } & \multicolumn{3}{|c|}{ \%cumulative amount of drug release } \\
\cline { 2 - 4 } & F5 & F6 & F7 \\
\hline $\mathbf{0}$ & 0 & 0 & 0 \\
\hline $\mathbf{1}$ & $2.27 \pm 0.005$ & $10.69 \pm 0.012$ & $8.15 \pm 0.011$ \\
\hline $\mathbf{2}$ & $12.27 \pm 0.014$ & $27.99 \pm 0.015$ & $26.02 \pm 0.016$ \\
\hline $\mathbf{3}$ & $39.18 \pm 0.010$ & $45.38 \pm 0.009$ & $42.22 \pm 0.009$ \\
\hline $\mathbf{4}$ & $61.92 \pm 0.110$ & $66.00 \pm 0.012$ & $59.10 \pm 0.020$ \\
\hline $\mathbf{5}$ & $83.80 \pm 0.120$ & $82.43 \pm 0.011$ & $79.60 \pm 0.018$ \\
\hline
\end{tabular}

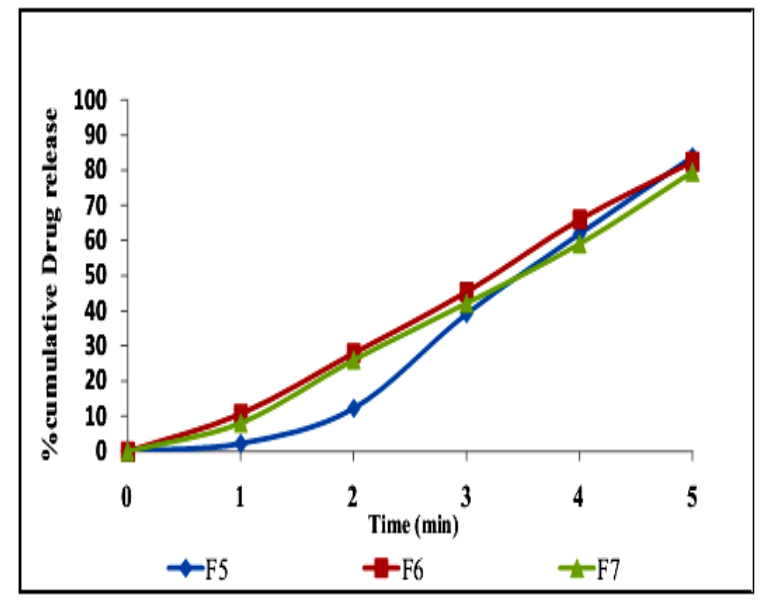

Table 7:-Cumulative \% Drug Release (F5 - F7) Fig 12:-Dissolution Profile of F5-F7 


\begin{tabular}{|c|c|c|c|}
\hline \multirow{2}{*}{ Time (Min) } & \multicolumn{3}{|c|}{ \% cumulative amount of drug release } \\
& & F9 & F10 \\
\cline { 2 - 4 } & F8 & 0 & 0 \\
\hline $\mathbf{0}$ & 0 & $1.06 \pm 0.014$ & $5.80 \pm 0.016$ \\
\hline $\mathbf{1}$ & $4.62 \pm 0.010$ & $12.65 \pm 0.008$ & $18.56 \pm 0.013$ \\
\hline $\mathbf{2}$ & $20.51 \pm 0.012$ & $37.79 \pm 0.035$ & $39.82 \pm 0.010$ \\
\hline $\mathbf{3}$ & $43.74 \pm 0.009$ & $59.15 \pm 0.009$ & $66.68 \pm 0.012$ \\
\hline $\mathbf{4}$ & $60.63 \pm 0.008$ & 59.15 & $78.99 \pm 0.110$ \\
\hline $\mathbf{5}$ & $78.40 \pm 0.011$ & $75.54 \pm 0.007$ & \\
\hline
\end{tabular}

Table 8:-Cumulative \% Drug Release (F8 - F10)

\begin{tabular}{|c|c|c|c|}
\hline \multirow{2}{*}{ Time (sec) } & \multicolumn{3}{|c|}{ \%cumulative amount of drug release } \\
& \multicolumn{3}{|c|}{} \\
\cline { 2 - 4 } & F11 & F12 & F13 \\
\hline 0 & 0 & 0 & 0 \\
\hline 30 & $24.80 \pm 0.012$ & $14.22 \pm 0.013$ & $16.57 \pm 0.010$ \\
\hline 60 & $46.68 \pm 0.010$ & $28.60 \pm 0.010$ & $29.79 \pm 0.015$ \\
\hline 90 & $62.99 \pm 0.017$ & $49.52 \pm 0.007$ & $51.10 \pm 0.012$ \\
\hline 120 & $79.99 \pm 0.009$ & $68.99 \pm 0.009$ & $67.84 \pm 0.014$ \\
\hline 150 & $90.22 \pm 0.011$ & $80.14 \pm 0.010$ & $81.73 \pm 0.009$ \\
\hline
\end{tabular}

Table 9:-Cumulative \% Drug Release (F11 - F13)

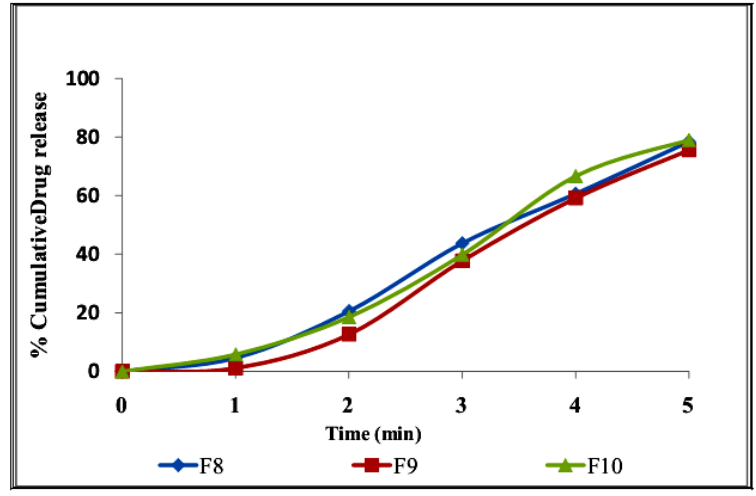

Fig 13:-Dissolution Profile of F8-F10

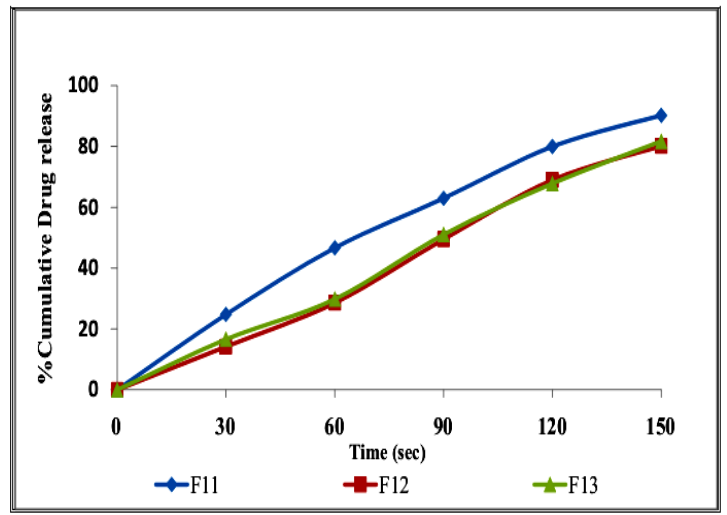

Fig 14:-Dissolution Profile of F11-F13

Table 10:-Cumulative \% Drug Release (F14 - F15) Fig 15:-Dissolution Profile of F14-F15

\begin{tabular}{|c|c|c|}
\hline \multirow{2}{*}{ Time (sec) } & \multicolumn{2}{|c|}{$\begin{array}{c}\text { \%cumulative amount of drug } \\
\text { release }\end{array}$} \\
\cline { 2 - 3 } & F14 & F15 \\
\hline 0 & 0 & 0 \\
\hline 30 & $27.34 \pm 0.008$ & $30.28 \pm 0.012$ \\
\hline 60 & $61.77 \pm 0.012$ & $66.88 \pm 0.010$ \\
\hline 90 & $85.42 \pm 0.009$ & $96.83 \pm 0.013$ \\
\hline 120 & $93.14 \pm 0.016$ & \\
\hline
\end{tabular}

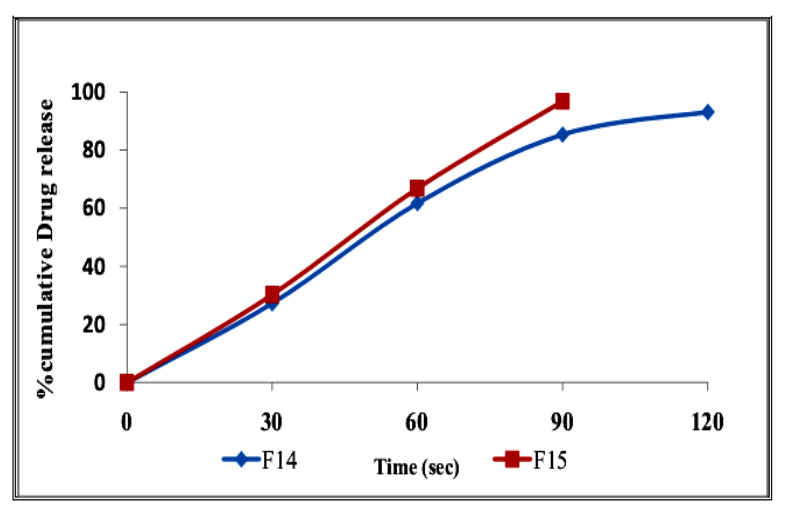

Stability studies:

The selected formulations was evaluated for short term stability studies which was stored at $40{ }^{\circ} \mathrm{C}$ at $75 \% \mathrm{RH}$ tested for 3 month and were analyzed periodically for their physical parameters, in vitro dispersion time and drug content at 30 days interval. The residual drug contents of formulations were found to be within the permissible limits and the values were shown in the tables below. 
Table 11:-Stability data of formulation F1

\begin{tabular}{|c|c|c|c|}
\hline \multirow{2}{*}{$\begin{array}{c}\text { Times in } \\
\text { Months }\end{array}$} & \multicolumn{3}{|c|}{ Formulation F1 stored at $\mathbf{4 0}$ ' $/ 75 \%$ RH } \\
\cline { 2 - 4 } & Physical appearance & In vitro Dispersion time & $\begin{array}{l}\text { \% Drug } \\
\text { content }\end{array}$ \\
\hline 1 & ++ & 2.00 & 93.91 \\
\hline 2 & +++ & 2.30 & 92.80 \\
\hline 3 & ++ & 2.40 & 92.65 \\
\hline
\end{tabular}

Table 12:-Stability data of formulation F11

\begin{tabular}{|c|c|c|c|}
\hline \multirow{2}{*}{$\begin{array}{c}\text { Times in } \\
\text { Months }\end{array}$} & \multicolumn{3}{|c|}{ Formulation F11 stored at $40^{\circ} \mathrm{C} / 75 \%$ RH } \\
\cline { 2 - 4 } & Physical appearance & In vitro Dispersion time & $\begin{array}{c}\text { \% Drug } \\
\text { content }\end{array}$ \\
\hline 1 & ++ & 2.45 & 95.63 \\
\hline 2 & +++ & 3.10 & 94.50 \\
\hline 3 & ++ & 3.20 & 94.10 \\
\hline
\end{tabular}

Table 13:-Stability data of formulation F15

\begin{tabular}{|c|c|c|c|}
\hline \multirow{2}{*}{$\begin{array}{c}\text { Times in } \\
\text { Months }\end{array}$} & \multicolumn{3}{|c|}{ Formulation F15 stored at $40^{\circ}$ C/ 75\% RH } \\
\cline { 2 - 4 } & Physical appearance & In vitro Dispersion time & $\begin{array}{r}\text { \% Drug } \\
\text { content }\end{array}$ \\
\hline 1 & +++ & 1.50 & 98.68 \\
\hline 2 & +++ & 2.30 & 97.45 \\
\hline 3 & ++ & 2.45 & 97.10 \\
\hline
\end{tabular}

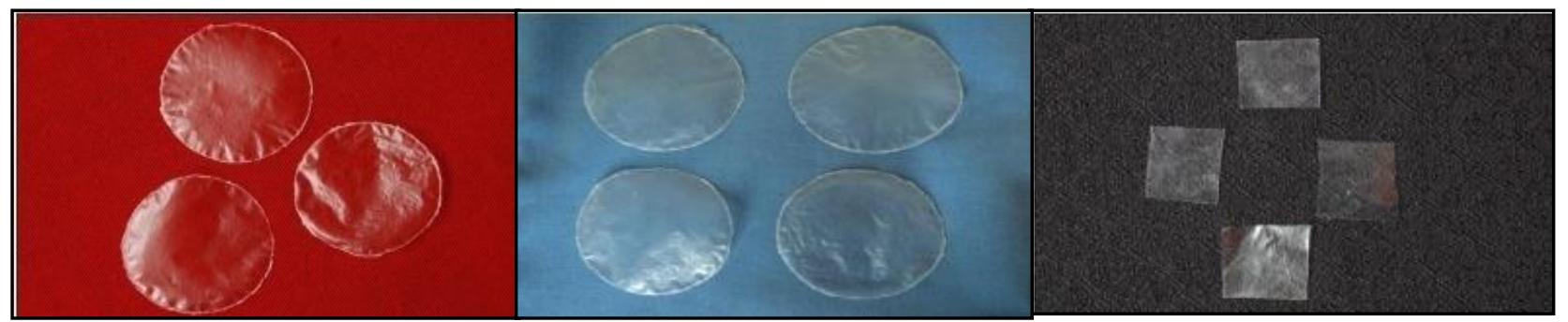

Fig 16:-Photograph of buccal films of Propranolol Hcl

\section{Conclusion:-}

In the present study fast dissolving drug delivery system of Losartan potassium were successfully developed in the form of fast dissolving oral films which offers a suitable and practical approach in serving desired objective of faster disintegration and dissolution characteristics with increase in patient compliance by avoiding the first pass metabolism and enhance the bioavailability of the drug.

\section{Reference:-}

1. Bhupendra G Prajapati, Nayan Ratnakar. A Review on Recent Patents on Fast Dissolving Drug Delivery System. Int.J.PharmTech Res.2009;1(3):790-798.

2. Kulkarni AS, Deokule HA, Mane MS, Ghadge DM. Exploration of different polymers for use in the formulation of oral fast dissolving strips. journal of current pharmaceutical research 2010; 2(1): 33-35.

3. Dixit R, Puthli S. Oral strip technology: Overview and future potential. journal of Control Release 2009;139:94107.

4. Kunte S, Tandale P. Fast dissolving strips: A novel approach for the delivery of verapamil. journal of pharmacy and bioallied science 2010; (4): 325-328.

5. Kumar D, Rathi L, Tipathi A, Maddheshiya YP. A review of oral mucosal drug delivery system. International journal of pharmaceutical science and research 2010; 1(5): 50-56.

6. Slowson M, slowson, S. What do when patients cannot swallow their medications. Pharma Times.1985;51:9096. 
7. Doheny K. You really expect me to swallow those horse pills? Am Druggist. 1993; 208: 34-35.

8. Nishimura M, Matsuur K, Tsukioka T, Yamashita H. In-vitro and In vivo characterstics of prochlorperazine oral disintegrating film. International journal of pharmaceutics 2009; 368: 98-102.

9. Schimoda H, Taniguchi K, Nishimura M, Matsuura K. Preparation of a fast dissolving oral thin film containing dexamethasone: a possible application to antiemesis during cancer chemotherapy . European journal of pharmaceutics and biophamaceutics 2009; 73: 361-365.

10. Tora -Tora Gorahowski. Principles of Anatomy and Physiology, 7th Edition edited by Gerad j. Tora-Tora and Sandro Reynolds Gorahowski, published Harpet Collins College Publishers; 1992:770-4.

11. Ross and Wilson. Anatomy and Physiology in Health and illness, 9th Edition edited by Anne Waugh and Allison Goraw published by Churchill livingstone Edinburgh; 2001:289-293.

12. International journal of Drug Development and Research apr-june 2010; 2(2) :232-246.

13. www.ondrugdelivery.com

14. Vondrak B, Barnhart S. Dissolvable Films for Flexible Product Format in Drug Delivery, Pharmaceutical Technology Supplement. April 2008.

15. Verena Garsuch. Preparation and Characterization of Fast dissolving Oral Films for Pediatric use ( dissertation). Dusseldorf, Heinrich-Heine University 2009; pp 13.

16. Basani Gavaskar, Subash Vijaya Kumar, Guru Sharan, Y. Madhusudan Rao. Overview On Fast Dissolving Films. International Journal of Pharmacy and Pharmaceutical Science. 2010; 2(3):29-33.

17. www.gasx.com.

18. Barnhart SD, Sloboda MS. The future of Dissolvable Films. Drug Delivery Technol. 2007;7(8):34-37.

19. Meathrel B, Mortiz C. Dissolvable Films and Their Potential in IVDs. IVD Technol. 2007;13(9):53-58.

20. Mishra R, Amin A. Quick API Delivery. Pharmaceutical Technology Europe: 1-5.

21. Coopens KA, Hall MJ, Mitchel SA, Read MD. Hypromellose, Ethyl cellulose and Polyethylene oxide used in Hot melt extrusion. Pharmaceutical Technology. Sep2005;1-6.

22. Frey P. Film Strips and Pharmaceuticals, Pharma.Mfg.\& Packag. Sourcer, winter.2006:92-93.

23. Arya A, Chandra A, Sharma V, Pathak K. Fast dissolving oral films: an innovative drug delivery system and dosage form. International journal of chemtech research 2010; 2(1): 576-583. 